\title{
MATERIAŁY
}

Daria Partyka

Bydgoszcz

\section{KOBIETA I RODZINA W EPIGRAMACH MARCJALISA}

Marcjalis był twórca epigramu' satyrycznego. Jego twórczość przypada na okres Wczesnego Cesarstwa. Analizując treść utworów Marcjalisa należy podkreślić różnorodność motywów kierujących autorem, który kreślił wizerunki kobiet. Jako bystry obserwator wszelkiego rodzaju słabości ludzkich nakreślił całą galerię niewiast reprezentujących określone wady i przywary. Jego epigramy nasycone są ironią i niewybrednym sarkazmem.

\section{Pochwala kobiety cnotliwej}

Marcjalis utrwalił w epigramach pozytywne przykłady życia kobiet. Chwaląc zasady ich cnotliwego życia, poeta prezentuje kilka wymownych sylwetek Rzymianek. Wysławiał ich zalety, charakter i urodę. Składał hołd jedynie tym kobietom, które uznał za najczcigodniejsze $\mathrm{i}$ warte pochwał. Marcjalis znał owe niewiasty osobiście, $\mathrm{z}$ autopsji lub z opowiadań.

Pierwszą kobietą godna pochwały Marcjalisa okazuje się Marcella. Wykształcona kobieta była patronką poety w czasie jego pobytu w Bilbilis. Marcjalis otrzymał od niej małą posiadłość wiejską ${ }^{2}$, która opisał w jednym z epigramów ${ }^{3}$. Upatrywano w Marcelli żony epigramatyka. Wysławiał jej zalety umysłu i serca, zacność i hojność:

Jaki duch, jakie serce! Cesarskie pokoje,

Niech cię by raz ustyszq, przyznaja za swoje;

Żadna ci nie dorówna... ${ }^{4}$

\footnotetext{
${ }^{1}$ Epigram to krótki utwór poetycki o charakterze aforystycznym, dowcipny, zamknięty zaskakująca puentą (Slownik terminów literackich, red. J. Sławiński, Wrocław-Warszawa-Kraków 1998, s. 133-134). Poniższe epigramy Marcjalisa zostały przełożone przez J. Czubka (M. Waleryusa Marcyalisa Epigramów Ksiag XII, thum. J. Czubek, Kraków 1908).

${ }^{2}$ M. Cytowska, H. Szelest, Literatura rzymska. Okres cesarstwa, Warszawa 1992, s. 316-317; H. Szelest, Marcjalis i jego twórczość, Wrocław 1963, s. 22; idem, Marcjalis i jego posiadlość w Nomentum, „Meander" 1998, nr 3, s. 274.

${ }^{3}$ Mar. XII 31.

${ }^{4}$ Mar. XII 21, 3-5.
} 
Marcella łagodziła tęsknotę za Rzymem i przypominała poecie jego wytworną kulturę:

Ty tęsknotę lagodzisz za grodem olbrzymem,

Co światu rozkazuje, tyś mi sama-Rzymem ${ }^{5}$.

Marcjalis docenił bohaterstwo i odwage żony Cecyny Petusa. Arrya popełniła samobójstwo w imię miłości do męża ${ }^{6}$.

Heroiczną postawę kobiety wobec męża przedstawił poeta w innym epigramie. Porcja, córka Katona Młodszego, dowiedziawszy się o śmierci męża Brutusa, sama postanawia odebrać sobie życie. Zrozpaczona szuka broni, wołając: Więc myślicie, że umrzé́, gdy zechcę, nie mogę? ${ }^{7}$ Wierna i dzielna małżonka połyka płomień i ginie.

W epigramie nagrobnym Marcjalis uczcił pewną matronę rzymską, okazał szacunek dla skromnej kobiety jako matki kilkorga dzieci, będącej przy okazji wzorem wierności małżeńskiej - cnoty tak bardzo propagowanej przez cesarza Domicjana:

Pięć cór i tyluż synów pieścilam na lonie,

Zamknęły mi powieki wszystkich dziatek dlonie;

I ta mi arcyrzadka dostala się chwata:

$W$ czystem tożu matżonka jednegom poznala ${ }^{8}$.

Marcjalis złożył szczególny hołd Sulpicji Młodszej, poetce żyjącej w I w. n.e. w czasach cesarza Domicjana. Zadedykował artystce dwa epigramaty ${ }^{9}$. Jeden zawiera pochwałę jej poezji, drugi, napisany z okazji rocznicy ślubu Sulpicji i jej męża Kalena, wysławia szczęśliwe małżeństwo ${ }^{10}$. Poeta porównał Sulpicję do nimfy o imieniu Egeria. Legendarna Egeria była doradczynią króla Numy, jego przyjaciółką lub żoną ${ }^{11}$. Marcjalis porównywał Sulpicje i Egerię, zrównując obie kobiety w sferze obyczajowej i moralnej. W jego przekonaniu nie ma kobiety bardziej czystej i uczciwej niż Sulpicja. Nimfa - bogini i poetka były tak samo nieskazitelne i przyzwoite. Porównanie Marcjalisa odnosiło się także do relacji małżeńskich pomiędzy Sulpicją a Kalenem oraz Egerii i Numy ${ }^{12}$.

Niech Sulpicya zacna czyta żona,

Co chce przez męża być tylko wielbiona;

Niech Sulpicyq mqż czyta ślubiony,

Co chce kochankiem być tylko swej żony [...]

Jej wiersz milosny zepsucia nie szerzy,

Choć pieszczot pelen i igry swawolnej.

Muzę Sulpicji ocenić kto zdolny,

I szczytem nazwie nieskalanej cnoty;

${ }^{5}$ Mar. XII 21, 9-10.

${ }^{6}$ Mar. I 13.

${ }^{7}$ Mar. I 42, 3 .

${ }^{8}$ Mar. X 63; M. Kuryłowicz, Prawo i obyczaje w starożytnym Rzymie, Lublin 1994, s. 111.

${ }^{9}$ Mar. X 35; 38; H. Szelest, Marcjalis $i$ jego..., s. 49.

${ }^{10}$ M. Cytowska, H. Szelest, Literatura rzymska..., s. 319, 345; D. Jędrzejczak, Sulpicja Mlodsza jako ziemskie wcielenie nimfy Egerii, „Meander” 2003, nr 1, s. 59.

"A. Krawczuk, Rzymianki, Warszawa-Kraków 1992, s. 33-36.

${ }^{12}$ D. Jędrzejczak, Sulpicja Mlodsza..., s. 60-72. 
Podobne figle stroita i psoty

Numie Egerja w glębi mokrej groty ${ }^{13}$.

Poeta zachwycał się pięknem poezji Sulpicji, nazwał jej wiersze swawolnymi, ale nie przynoszącymi zgorszenia. Artystka uczy amores, czystych zachowań miłosnych. Sulpicję można określić mianem univira, żona jednego męża, wierna i kochająca aż po grób. Po śmierci Kalena żona pogrążyłaby się w rozpaczy. Lojalna kobieta Żyć by nie chciała po Kalena stracie ${ }^{14}$ i z pewnością nie przyjęłaby nawet pięknego Apollina w swej komnacie.

Pochwałę cnót kobiecych Marcjalis wyraził w epigramie poświęconym rzymskiej poetce Teofilii. Kobieta odznacza się mądrościa, dobrze zna mędrców ateńskich i ja stoicka drużyna pragnie nazwać swoja ${ }^{15}$. Poeta dodał pochwałe, że nad cala plciq swoja góruje i thumem $^{16}$. Marcjalis, przeciwstawiając Teofilę i Safonę, tę pierwszą określił jako bardziej uczoną i zacną ${ }^{17}$.

Marcjalis wysławiał czcigodną małżonkę, Nigrynę, za miłość jaką darzyła swego męża. Poeta wyraża pogląd, że nie trzeba umierać wraz z mężem na stosie (jak bohaterska Eudahne), by udowodnić miłość małżeńską. Trzeba to raczej czynić przez dochowywanie wierności i przestrzegania postanowień przodków ${ }^{18}$.

\section{Kobiety rozpustne}

Epigramy poświęcone kobiecym wadom i słabostkom można pogrupować, tworząc określone typy zachowań. Marcjalis przedstawił całą galerię różnego rodzaju kobiet: niewiernych, rozpustnych, brzydkich, starych, nadużywających alkoholu. Bezceremonialnie obnażył niewieście występki i poczynania, nie żałując ironii i sarkazmu. W epigramach zdemaskował bezwstyd, pruderię i natarczywą kokieterię Rzymianek. Poeta narzekał na powszechny upadek moralności i obyczajów oraz nadmierną swobodę seksualną kobiet ${ }^{19}$. Wnikliwe obserwacje rzymskiego życia doprowadziły go do poniższego wniosku:

Zaczepiajac dziewczyny, wciąz się zastanawiam,

Czy też która nie odmówi. Żadna nie odmawia.

Jakby zbrodniq lub hańbq miala być odmowa

Albo byl jakiś zakaz - każda jest gotowa.

„Więc cnotki wyginęty?" - Nie, mnóstwo ich chodzi!

„No i co?" - Taka nie chce, ale też sie godzi $i^{20}$.

\footnotetext{
${ }^{13}$ Mar. X 35.

${ }^{14}$ Mar. X 35, 20; D. Jędrzejczak, Sulpicja Mlodsza..., s. 66-67; J. Carcopino, Życie codzienne w Rzymie w okresie rozkwitu cesarstwa, Warszawa 1966, s. 94-95.

${ }^{15}$ Mar. VII 69, 4.

${ }^{16}$ Mar. VII 69, 6.

${ }^{17}$ Mar. VII 69, 9-10; D. Jędrzejczak, Sulpicja Mlodsza..., s. 64.

${ }^{18}$ Mar. IV 75, 1-3, 7-8; J. Carcopino, Życie codzienne..., s. 94.

${ }^{19}$ M. Kuryłowicz, Prawo i obyczaje..., s. 106-120.

${ }^{20}$ Mar. IV 71, (Marcjalis, Epigramy, wybór, thum. S. Kołodziejczyk, Warszawa 1985).
}

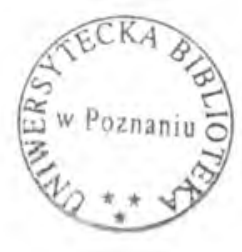


Lesbię ganił za bezwstydność i jawność rozpusty. Kobieta przy otwartych drzwiach dopuszcza się niemoralnych zachowań, tylko po to, by zyskać widza swoich poczynań:

[...] Jawnie i bez zaslony odprawiasz swe grzeszki;

Nie o gaszka tu chodzi, lecz o widza raczej

I nic rozkosz u ciebie ukryta nie znaczy ${ }^{21}$.

Rozpustę kobiet poeta przedstawił poprzez sylwetki kobiece o imieniu Tais ${ }^{22}$, Taida ${ }^{23}$, Lukrecja. Kobiety nie potrafiły odmówić sobie przyjemności, nawet pod groźbą narażenia się na pośmiewisko całego miasta. Marcjalis zwrócił się do niejakiej Tais ze słowami wytykającymi jej występki:

Nikomu nie odmawiasz $i$ wstydu nie zdradzasz;

Jednego wstydź się, Tais: na wszystko się zgadzasz! $!^{24}$

Marcjalis piętnował kobiety niewybredne w wyborze kochanków. Kochankiem Celii może być Part, German, Kapadok, Sarmata czy Hindus. Nie odmawia żadnemu z nich. Poeta kwituje słabostkę Celii pytaniem:

Powiedz, Rzymianko, czemu przy takim wyborze

Tylko ci się Rzymianin spodobać nie może? ${ }^{25}$

Wedhug Marcjalisa kobieta o niewybrednym guście jest łatwa, za parę denarów przyjmuje czcicieli ${ }^{26}$, a nawet calq naraz trójke względami obdzieli ${ }^{27}$. Wraz ze wzrostem jej usług staje się pyszna i nosek do góry zadziera ${ }^{28}$.

Epigramatyk dosadnie nakreślił sylwetkę kochanki obłudnej i pełnej fałszywego wstydu:

Spać chcesz razem, a nie chcesz, bym cię widzial w wannie.

Nie wiem, jakq ulomność skrywasz tak starannie.

Czy ci piersi zwisajq jak dwa smutne flaki,

Czy brzuch zdradza niechybne starości oznaki? [...]

Nic z tych rzeczy. Doprawdy, najladniejszas - gola.

Jeśli masz jakqś wadę, to gorszq: fiola ${ }^{29}$.

Rozszerzeniem powyższego utworu jest nieskrępowane opowiadanie autora:

Byla u mnie noc cala, swawolna i pusta

Filutka nad filutki, chodzqca rozpusta.

Syt pieszczot, blagam o to... [...]

Jeszczem mówić nie skończyl, już spełnia mq wolę ${ }^{30}$.




Marcjalis bez skrępowania piętnuje homoseksualne skłonności niektórych rzymskich kobiet. Bassie wyrzuca, że otacza się służbą złożoną tylko z kobiet i czerpie przyjemność $\mathrm{z}$ intymnych kontaktów $\mathrm{z}$ towarzyszkami:

Wszyscy się zachwycali twym dziewiczym wiankiem,

Nie wiedzac, że - o zgrozo - ty jesteś kochankiem.

Rozkoszq ośmielacie darzyć się nawzajem

I jedna wobec drugiej mężczyznę udaje.

Do tej zagadki chyba sam Sfinks by się przyznal:

W jakim to cudzolóstwie zbędny jest mężcyyzna? $?^{31}$

\section{Kobiety niewierne}

Cesarz Domicjan odnowił wydane przez Augusta ustawy. Mąż zastawszy żonę z kochankiem, miał obowiązek się z nią rozwieść. Jeśli tej powinności nie uczynił, to mógł być oskarżony o stręczycielstwo i podlegać karze. Mimo surowych przepisów wielu mężów przymykało oczy na występki swych żon ${ }^{32}$. Marcjalisowa galeria kobiet niewiernych i zdradzających mezzów stanowi główny trzon epigramów satyrycznych ${ }^{33}$.

Wyśmiewal Marcjalis postępowanie Kandygi, który zajęty sprawami gromadzenia dóbr i majątku, nie zauważa licznych zdrad swojej małżonki:

Sercem też i rozumem nie dzielisz się z nikim -

Wszystko to masz dla siebie, prawda, ani slowa:

Tylko żona, Kandydzie, wlasność narodowa ${ }^{34}$.

Obłudna i rozpustna żona obdarzała względami pięknego młodzieńca, właściwie na oczach małżonka. Panicz nie odstępuje od swej pani, szepcze mile rzeczy na ucho, przesuwając pierścienie na palcu. Marcjalis wyśmiewa głupotę męża, zadowolonego z pracy eleganckiego i młodego rządcy majątku, kwitując sytuację krótko i z humorem:

Sprawy żony zalatwia młodzian kędzierzawy...

Nie żony, prędzej twoje zalatwia on sprawy ? $^{35}$

Przebiegle żony nie przebierają w środkach, by dopiąć celu. Pragnąc wyjść $\mathrm{z}$ domu i spotkać się z gachem, wymyślają przeróżne kłamstwa. Na przykład Paula pozoruje chorobę rodziców lub przyjaciółki ${ }^{36}$.

\footnotetext{
${ }^{31}$ Mar. I 90, 5-10.

${ }^{32}$ A. Tawracka, $W$ krzywym zwierciadle: rozwód. Satyrycy okresu pryncypatu o repudium, w: Contra leges et bonos mores. Przestepstwa obyczajowe $w$ starożytnej Grecji $i$ Rzymie, red. H. Kowalski, M. Kurylowicz, Lublin 2005, s. 355-356; M. Kuryłowicz, Prawo i obyczaje..., s. 112-114; A. Krawczuk, op.cit., s. 108-109; W. Pabiasz, Charakter instytucji malżeństwa w starożytnej Grecji i Rzymie, „Homo Dei” 1979 , nr 3, s. 221-223.

${ }^{33}$ Mar. I $34 ; 62 ; 74 ;$ II $4 ; 56 ; 60 ; 83 ;$ III 26; 70; 85; IV 5; 16; V 61; VI 6; 7; 39; 90; VIII 31; X 91; 95; XI 7; 43; 71; XII 42; 52; 58; 93.

${ }^{34}$ Mar. III 26.

${ }^{35}$ Mar. V 61, 13-14.

${ }^{36}$ Mar. XI 7, 7-10.
} 
Niektóre kobiety ukrywają swoje żądze pod płaszczykiem pokrewieństwa: związek macochy z pasierbem ${ }^{37}$ lub starej kobiety, którą młody kochanek nazywa matką lub siostrą ${ }^{38}$.

Niewierna żona potrafiła nawet uwieść przyjaciela swojego męża ${ }^{39}$. Rzymianki pragnęły pieszczot i brały sobie za kochanków eunuchów. Dodatkową zaletą tego związku była niemożność zajścia w ciążż .

Cynnę również poeta wystawił na pośmiewisko. Mężczyzna posiada siedmioro dzieci, ale żadne $\mathrm{z}$ nich nie jest jego. Gromadka jest owocem zrodzonym ze związków jego żony $z$ niewolnikami. Marcjalis rozpoznaje w każdym dziecku podobieństwo do ich naturalnego ojca, na przykład po płaskim nosie czy dużych uszach. Marulla poczęła dzieci z murzynem, kucharzem, piekarzem, szermierzem, a córki z rządcą i grajkiem.

Wszyscy splodzeni na pryczach i slomie,

Żywe matczynej dowody niestawy ${ }^{41}$.

Nienasycone rzymskie matrony nie potrafiły się nasycić jednym kochankiem. Zaspokajały swoje żądze mając kilku gachów naraz ${ }^{42}$.

Obiektem westchnień rzymskich dam byli aktorzy oraz atleci ${ }^{43}$.

\section{Marcjalis o malżeństwie}

Marcjalis patrzył na małżeństwo w charakterystyczny dla siebie sposób. Przywoływał ustawy julijskie, mające na celu poprawę obyczajów i odbudowanie instytucji małżeństwa. Potęiał mieszkańców Rzymu nieprzestrzegających ustawy:

Dość rozpusty: malzenskie dziś górq okowy!

Czysta ma być Wenera: brzmi rozkaz surowy ${ }^{44}$.

Nawoływał do czystości obyczajów, zwłaszcza w rodzinie:

Odkad prawo Julijskie wskrzesto, Faustynie

I wstyd miejsce odzyskal należne rodzinie $[\ldots]^{45}$

Marcjalis zauważa, że partnerzy w małżeństwie są siebie warci. Życie małżeńskie opiera się nie na wspólnocie, ale na dbaniu tylko o osobiste interesy:

Maż ladaco, szelma żona:

Parka dla siebie stworzona;

O brylanty jednej wody,

Czemuż u was nie ma zgody? $?^{46}$

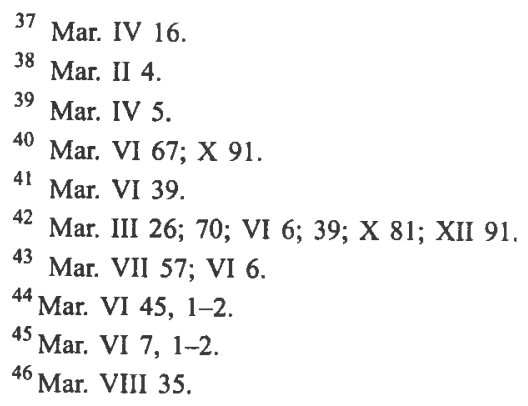


Miniaturką sytuacji między małżonkami jest krótki epigram:

Dziewczarzem zwie cię żona, a sama tragarka:

To dopiero, Alaudo, dobrana $z$ was parka! $!^{47}$

Poeta nie wierzył w równość praw w małżeństwie. Nie mógłby znieść władczej żony i nie potrafiłby podporządkować się małżonce:

Gdzie, mój Prysku, nad mężem górę żona bierze,

Żeby tam byla równość - po prostu nie wierzę $e^{48}$.

Żona u Marcjalisa jest postrachem całej rodziny. Poeta nie zaprzeczyłby opinii, że dobra żona to martwa żona. Nierzadko zatem mąż życzy sobie śmierci małżonki:

Przyjaciólki Likorys wszystkie grzebie w kólko:

Ach, czemuz mojej zonie nie jest przyjaciólkq. $!^{49}$

Idealna kandydatka na żonę powinna być bogata, młoda i piękna, ale nie może się zbytnio przechwalać i być pewna siebie ${ }^{50}$.

W oczach epigramatyka nie jest mile widziane u kobiet przywiazanie do rzeczy materialnych: klejnotów, pieniędzy i złota ${ }^{51}$. Gelia nie przeżyłaby ani godziny bez świecidełek:

Perlom wyciska pocatunki mnogie,

To jej braciszki, to siostrzyczki drogie ${ }^{52}$.

Mężowskie wymówki nie mają końca w jednym z humorystycznych epigramów księgi jedenastej:

Żono, albo się rozwiedź, lub przystósuj do mnie:

Jam nie Numa ani Tacy, nie żyje tak skromnie.

Ja pić lubię do późna w biesiadników kole [...]

Ciebie stoni przepaska, tunika, plachetka:

Dla mnie nigdy, przenigdy dość naga kobietka. [...]

Chcesz dorównać Lukrecji w powadze $i$ wstydzie:

Bądź podobna jej we dnie, lecz w nocy - Taidzie ${ }^{53}$.

Marcjalis opisuje intymną stronę pożycia małżeńskiego. Żona nie potrafi lub nie chce sprostać wymaganiom erotycznym męża. Ona ma inne upodobania. Małżonek oczekuje aktywności we wzajemnym pożyciu. Wspomniana w utworze Lukrecja to symbol wiernej żony, a Taida to uosobienie kobiecej żądzy i bezwstydu. Mąż grozi żonie, że jeśli nie spełni jego oczekiwań, to rozwiedzie się z nią.

Rozwody w Rzymie bywały bardzo częste. Repudium mógł zażądać mąż, jak i żona. Prokuleja rozwiodła się z małżonkiem ze względów finansowych. Jej mąż bowiem objął

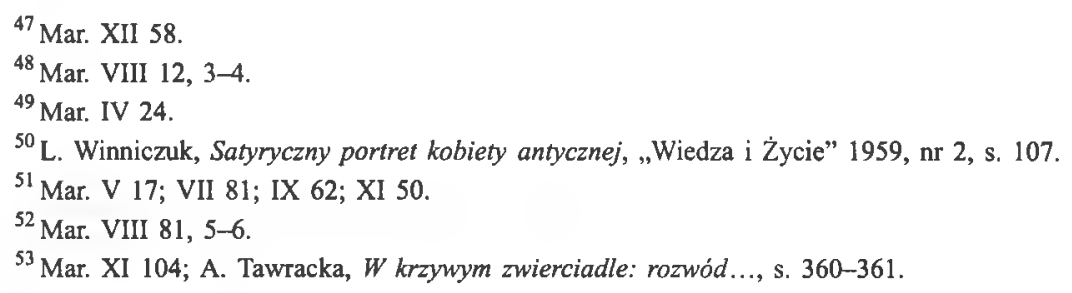


stanowisko pretora, co się wiązało z zobowiązaniami i kosztami. Marcjalis uważa owy rozwód zyskiem dla Prokulei ${ }^{54}$.

Ustawy Augusta miały ograniczyć częstotliwość rozwodów i zakazywały ponownego małżeństwa tuż po repudium. W epigramie skierowanym do Telezylii, Marcjalis powohuje się na owe przepisy prawa. Odkąd prawo Julijskie wskrzeslo, to wstyd miejsce odzyskat nalezine $w$ rodzinie, ale:

Uptynęto wszystkiego dni ledwie trzydzieści,

A męża Telezylla dziesiatego pieści.

Nie to żona, lecz chyba nalożnica prawna:

Milsza mi już publiczna grzesznica i jawna! $!^{5 s}$

Marcjalis uważa, że kobieta, która wiele razy wychodzi za mąż, nie zawiera związku małżeńskiego. Telezylla próbuje ominąć ustawę i uniknąć odpowiedzialności za niewierność małżeńską. Dla poety częste zmiany małżonków to cudzołóstwo i rozpusta.

Dla Marcjalisa jedynym idealnym związkiem kobiety i mężczyzny było małżeństwo Sulpicji i Kalena. Para jest symbolem miłości i wierności małżeńskiej. Łączy ich najpiękniejsze uczucie. Poeta sławi Sulpicję jako idealną żonę i ucieleśnienie bogini w epigramie księgi dziesiątej ${ }^{56}$. W innym utworze zwraca się do Kalena $z$ okazji rocznicy ślubu ${ }^{57}$.

Kalen jest przedstawiony jako wierny i kochający swą żonę mąż. Mężczyzna odznaczał się szlachetnością i postępował według zasad moralnych. Kalen jest oddany swej żonie, podobnie jak legendarny król Numa ${ }^{58}$.

Kwintesencją istoty miłości, zwłaszcza małżeńskiej są słowa Marcjalisa:

Chcesz być kochany, kochaj czynami, nie stowy! $!^{59}$

\section{Kobiety nadużywające wina}

Pijaństwo kobiet należało do grupy występków przeciwko zasadom obyczajowości i moralności. W dawnym Rzymie istniało prawo zakazujące kobietom spożywania wina. Mąż w swojej severitas miał prawo zabić żonę, która złamała zakaz. Zwyczajowy pocałunek kobiety w usta przez krewnych płci męskiej miał służý sprawdzeniu, czy nie raczyła się ona zakazanym trunkiem. Uważano, że pociąg do wina zamykał kobiecie drzwi do cnoty, a prowadził do utraty samokontroli i występkom przeciw dobrym obyczajom ${ }^{60}$.

\footnotetext{
${ }^{54}$ Mar. X 41; A. Tawracka, W krzywym zwierciadle: rozwód..., s. 359-360; L. Winniczuk, Ludzie, zwyczaje i obyczaje starożytnej Grecji i Rzymie, Warszawa 1983, s. 252.

${ }^{55}$ Mar. VI 7; J. Carcopino, Życie codzienne..., s. 102-105; A. Tawracka, W krzywym zwienciadle: rozwód..., s. 358-359.

${ }^{56}$ Mar. X 35; D. Jędrzejczak, Sulpicja Mtodsza..., s. 62-72.

${ }^{57}$ Mar. X 38.

${ }^{58}$ D. Jędrzejczak, Sulpicja Mtodsza..., s. 67-68.

${ }^{59}$ Mar. VI 11, 10.

${ }^{60}$ I. Błaszczyk, Niewierność, rozpusta oraz obluda kobiet jako element rzymskiej rzeczywistości wedlug epigramów Marcjalisa, w: Contra leges et bonos mores..., s. 49; D. Musial, Zakaz picia wina przez rzymskie kobiety. Przyczynek do dziejów religii $i$ obyczajów, w: Crimina et mores. Prawo karne $i$ obyczaje $w$ starożytnym Rzymie, red. M. Kuryłowicz, Lublin 2001, s. 121-127; M. Kuryłowicz, Prawo i obyczaje ..., s. 90-105.
} 
Marcjalis w satyrycznym tonie kreśli sylwetki kobiet pijanych i nadużywających wina. Niewiasty próbują zakamuflować poranne skutki picia i towarzyszący temu niemiły zapach $\mathrm{z}$ ust. Używają w tym celu pastylek, kupowanych u rzymskiego drogerzysty $\mathrm{Kosmy}^{61}$. Pewna kobieta chcąc ukryć przykry zapach z ust, żuje liście wawrzynu ${ }^{62}$. Nadużywanie wina prowadzi wedhug Marcjalisa do zbytków i rozwiązłości seksualnej ${ }^{63}$.

Marcjalis bezlitośnie kpi ze słabości rzymskich pań. Poeta opowiada w jednym z epigramów o pięknej Fyllis. Po upojnej nocy Marcjalis zastanawia się, czym obdarować kochankę: perfumami, złotem czy wonnymi olejkami. Jednak Fyllis ku zaskoczeniu pragnie innej nagrody:

W tem mi się rzuci dziewczyna na szyje,

I wciqż calujac, na wszystko zaklina,

Bym jej darowal - co? - amfore wina! ${ }^{64}$

\section{Brzydota kobiet}

Utwory satyryczne Marcjalisa są przepelnione postaciami kobiet brzydkich i z wadami fizycznymi ${ }^{65}$. Poeta miał wiele do zarzucenia w kwestii urody kobiecej. Bystry obserwator dostrzegał liczne mankamenty fizyczne niewiast. Portret kobiety w marcjalisowej satyrze nie jest zachęcający. Mężczyzn odpychały kobiety łyse ${ }^{66}$, w peruce ${ }^{67}, z$ brakami w uzębieniu $^{68}$, z jednym okiem ${ }^{69}$, zbyt chude ${ }^{70}$, o nieciekawym głosie ${ }^{71}$ czy używające nadmierne ilości perfum ${ }^{72}$.

Marcjalisowi nie podobały się kobiety zbyt chude, co wiotka na kochanie, Co jej ramiqczko mój pierścién obstanie, [...] kolanem rani, a $W$ grzbiecie ma pitę ${ }^{73}$. Nie preferuje pań otyłych, co kwituje z przekąsem: Miesso rad jadam, lecz sadla nie znosze $e^{74}$. Według poety kobiety $z$ nadwagą powinny płacić potrójny wstęp, chcąc wejść do łaźni ${ }^{75}$.

Poeta wyśmiewa Kwintusa za staranie się o względy nieurodziwej Taidy:

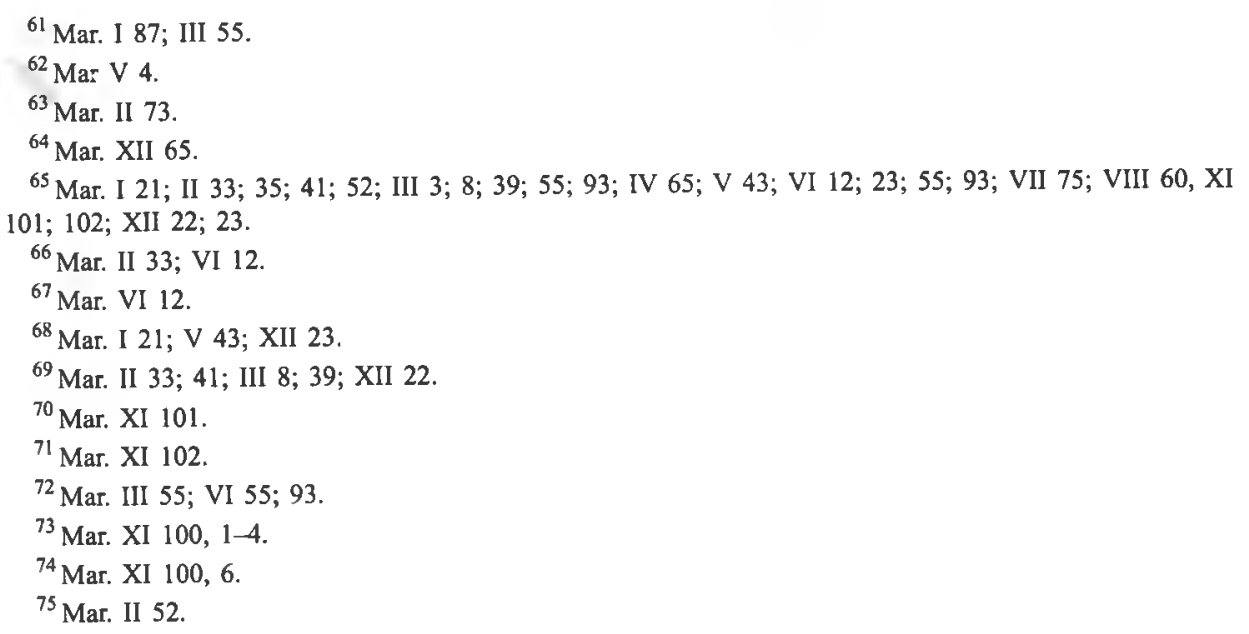


W jednookiej Taidzie Kwintus się, niebożę,

Zakochal. Kto z nich dwojga - powiedz - widzi gorzej $?^{76}$

Marcjalis uważa za rozpustę flirty z brzydkimi kobietami:

Łysaś, rudaś, bez oka: calować cię w usta

Sprosina, przeciw naturze bylaby rozpusta ${ }^{77}$.

Do Filenis skierował następujący epigram:

Jednem okiem Filenis placze, nie obiema;

Dlaczego? - Powód prosty: bo drugiego nie $\mathrm{ma}^{78}$. i zęby:

Poeta z Bilbilis bez skrępowania kpił z rzymskich pań kupujących sztuczne włosy

Klnie się Paula na bogi, że ma wlosy wlasne,

Choć kupiła: nie krzywo przysięgla, to jasne ${ }^{79}$.

Do Lelii zwrócił się w podobny sposób:

Kupne zęby $i$ wlosy sztukuja ci postać:

Cóż z okiem będzie, Leljo? - Trudno pono dostac ${ }^{80}$.

Marcjalisowi nie przypadają do gustu kobiety spryskane nadmierną ilością wonności i perfum ${ }^{81}$. Uważa, że wszelki nadmiar kosmetyków szkodzi. Gdziekolwiek pojawia się Gelia, czuć zapach całej perfumerii Kosmy ${ }^{82}$.

Marcjalis porównuje zapach Tais do licznych obrzydliwych zapachów rzymskiego miasta. Mimo że kobieta nakłada na siebie przeróżne mikstury, niemiły zapach nie jest możliwy do zneutralizowania. Tais nadal przypomina zapachem portowego psa, stare jajko czy zepsutą rybę ${ }^{83}$.

\section{Satyra na stare kobiety}

Marcjalis bez pobłażliwości traktował kobiety stare ${ }^{84}$. Kpił ze starzejących się rzymskich dam, które z przesadą dbają o urodę. Stosując różne kosmetyka i mikstury, pragnęły się odmłodzić za wszelką cenę. Przenikliwy obserwator z Bilbilis zauważa oznaki starzenia się próżnych kobiet i poddał krytyce chęci wyglądania młodszą i atrakcyjniejszą niż się jest w rzeczywistości.

${ }^{76}$ Mar. III 8, thum. S. Kołodziejczyk.

${ }^{77}$ Mar. II 33.

${ }^{78}$ Mar. IV 65.

${ }^{79}$ Mar. VI 12.

${ }^{80}$ Mar. XII 23; E. Skwara, Teatr Marcjalisa, w: Epigram grecki i laciński w kulturze Europy, red. K. Bartol, J. Danielewicz, Poznań 1997, s. 193; Kobiety świata antycznego, red. L. Winniczuk, Warszawa 1973, s. 411; L. Winniczuk; Satyryczny portret kobiety..., s. 107.

${ }^{81}$ Mar. III 55; VI 55; 93.

${ }^{82}$ Mar. III 55.

${ }^{83}$ Mar. VI 93.

${ }^{84}$ Mar. I 83; II 34; 41; III 42; 93; IV 20; VII 75; 113; VIII 79; IX 29; 37; X 8; 37; 90. 
Uwadze poety nie uszedł niezawodny sposób starzejących kobiet usiłujących zabłysnąc w towarzystwie. Stwarzały sobie tło z kobiet brzydszych i starszych po to, by wyglądać młodziej:

Wszędzie przy tobie ta gwardia szkaradna:

Na tym tle - nie dziw - ześ mioda i ladna ${ }^{85}$.

Starzejące się kobiety używały mikstur i maści, by powstrzymać gasnącą urodę i uciekający czas. Kosmetyki nie zastępowały młodości, a ich nadmiar wręcz szkodził. Leciwe damy starały się wabić mężczyzn i nabrać naiwnych na młodszy wiek:

Zęby na noc z odzieniem skladasz, by wdziać z rana,

I maściq ze stu slojów śpisz usmarowana,

Maska twarz zastoniwszy. - I ty, taka larwa,

Wabisz brwiq co ja rano podznaczyla barwa! ${ }^{86}$

Sam Marcjalis doświadczył zalotów starej i chciwej rozpustnicy:

Za darmo-ć się zachciewa, babo podstarzala?

A to dobre: dać nie chcesz, a chętnie byś data ${ }^{87}$.

Dla Hekuby poeta nie miał litości. Bardzo dosadnie i szyderczo przedstawił kobiece występki i starczą brzydotę:

Lat setkę pewnie żeś, Hekubo,

Juz przekroczyla, i to grubo.

Trzy wlosy masz na glowie, $z$ geby

Sterczq ci tylko cztery zęby,

Skóra na twarzy pomarszczona [...]

Kozlem od ciebie czuć na milę,

I masz na kość wyschnięta dziuple. [...]

Po dwustu mężach, stara szmato,

Jeszczeć jednego się zachciewa?

I chlop ma lec przy takim próchnie? ${ }^{88}$

Marcjalis nie litował się nad wdowami ${ }^{89}$, zwłaszcza tymi, które straciły kilku mężów:

Siedmiu swym nieboszczykom na kamieniu ryje,

Że to ona sprawila: no, ta się nie kryje ${ }^{90}$.

Epigramy Marcjalisa są krzywym zwierciadłem realnego świata. Ukazują przerysowaną i skarykaturyzowaną rzymską rzeczywistość. Nie należy słów poety brać dosłownie. Czytelnik powinien spojrzeć na marcjalisowe epigramy jak na satyrę obyczajowa.

\footnotetext{
${ }^{85}$ Mar. VIII 79; Kobiety świata antycznego..., s. 411; L. Winniczuk, Satyryczny portret kobiety...s. 107.

${ }^{86}$ Mar. IX 37.

${ }^{87}$ Mar. VII 75, thum. S. Kołodziejczyk.

${ }^{88}$ Mar. III 93, thum. S. Kolodziejczyk.

${ }^{89} \mathrm{Mar}$. VI 7; IX 15; IX 78; E. Wipszycka, Wdowie niedole, wdowie ambicje, o wdowach $w$ Kościele pierwszych wieków, „Mówią Wieki” 1994, nr 2, s. 2

${ }^{90}$ Mar. IX 15.
} 